\title{
IMPLEMENTASI METODE WEBQUAL DAN CUSTOMER SATISFACTION INDEX UNTUK MENGEVALUASI WEBSITE PERGURUAN TINGGI NEGERI DI BANDAR LAMPUNG
}

\author{
1 Tristiyanto, ${ }^{2}$ Deviana Saputri, ${ }^{3}$ M. Iqbal \\ Jurusan Ilmu Komputer, Fakultas MIPA, Universitas Lampung \\ Jl. Prof. Dr. Soemantri Brodjonegoro No. 1 Bandar Lampung 35145 \\ 1 tristiyanto.1981@fmipa.unila.ac.id, ${ }^{2}$ devianasaputri22@gmail.com, \\ ${ }^{3}$ muhammadiqbal@fmipa.unila.ac.id
}

\begin{abstract}
This study provides an overview of the quality of six state University website services in Bandar Lampung which refered to three dimensions, website usability, information quality, and interaction quality website. This study also used the Customer Satisfaction Index (CSI) method to determine the level of user satisfaction. In addition, to improve the usability of a website, website performance testing was performed using automatic tools. The result of this research find that the quality of website services is influenced by the content on the website. The result of CSI analysis on the website of state Universities in Bandar Lampung are satisfied with the website service at each state University in Bandar Lampung. Based on the results of the usability evaluation using automatic tools on the website, it is known that the website of state Universities in Bandar Lampung is good enough as evidenced by the page load time value which was less the three seconds.
\end{abstract}

Keywords: Quality of Website Service, WebQual, CSI, Usability

\begin{abstract}
Abstrak
Penelitian ini mengkaji kualitas layanan pada enam website universitas negeri di Bandar Lampung dengan menggunakan metode Webqual yang merujuk pada 3 hal yaitu website usability, kualitas informasi dan kualitas interaksi website. Kepuasan pengguna diukur menggunakan metode Customer Satisfaction Index (CSI). Untuk meningkatkan website usability dilakukan website performance tes menggunakan alat otomatis. Hasil dari penelitian ini memperlihatkan kualitas layanan website dipengaruhi oleh konten website. Sedangkan hasil Analisa CSI pada website universitas negeri di Bandar Lampung adalah memuaskan untuk setiap website universitas tersebut. Berdasarkan hasil evaluasi usability, website universitas negri di Bandar Lampung menunjukkan sudah cukup baik dengan waktu load halaman kurang dari tiga detik.
\end{abstract}

Kata Kunci: Kualitas Layanan Website, WebQual, CSI, Usability 


\section{PENDAHULUAN}

Pembuatan website Perguruan Tinggi saat ini mempunyai tujuan diantaranya adalah untuk memberikan informasi mengenai profil, program akademis, sarana dan fasilitas, kegiatan yang telah dan akan berlangsung, capaian yang telah diperoleh dan lain sebagainya. Masyarakat secara luas akan melihat dan mengakses website universitas sebagai interaksi pertama dan daya tarik terhadap universitas tersebut. Peranan website suatu perguruan tinggi sebenarnya tidak hanya terbatas sebagai media informasi namun juga untuk menyediakan layanan yang dapat memberikan berbagai kemudahan baik bagi anggota civitas akademika maupun calon civitas yang akan bergabung dengan perguruan tinggi tersebut [1]. Oleh karena itu, memberikan pelayanan yang terbaik dalam bidang teknologi informasi merupakan suatu upaya untuk memberikan kepuasan kepada mahasiswa. Berdasarkan hal tersebut, penelitian ini mencoba untuk mengukur kualitas layanan website dari sisi kepuasan pengguna akhir dan mengevaluasi performance dari website tersebut.

Kualitas website akan sangat berpengaruh terhadap tingkat kepuasan penggunanya itu sendiri. Semakin tinggi kualitas suatu web, maka akan semakin banyak pengguna yang mengakses website tersebut [2]. Mengukur kualitas website merupakan salah satu langkah penting yang perlu dilakukan guna mengembangkan website tersebut agar sesuai dengan tujuan dan harapan para penggunanya.

Salah satu metode yang digunakan untuk mengukur kualitas layanan website adalah webqual yang merupakan metode atau teknik pengukuran kualitas website berdasarkan persepsi pengguna akhir. Dalam penelitian [3] mengemukan webqual memiliki tiga dimensi kualitas yaitu, pertama kualitas informasi (information quality), sebagai kualitas konten/isi dari website, kedua kualitas interaksi (interaction quality) yaitu kualitas pengalaman interaksi pengakses, dan ketiga adalah kesiapan pakai situs (website usability) yaitu kualitas yang dihubungkan dengan kesiapan pakai dan desain suatu situs [4].

Pengguna akan merasa terpuaskan jika persepsi tentang kualitas layanan website yang dirasakan saat ini sesuai dengan tingkat harapan pengguna. Tingkat kepuasan pengguna terhadap layanan website bisa diukur menggunakan Customer Satisfaction Index (CSI). CSI merupakan analisis kuantitatif berupa persentase pelanggan dalam suatu survey kepuasan pelanggan. CSI diperlukan untuk mengetahui tingkat kepuasan pelanggan secara keseluruhan dengan memperhatikan tingkat kepentingan dari atribut-atribut produk dan jasa [5].

Dalam penelitian ini juga akan dilakukan evaluasi usability (kegunaan website) yang digunakan untuk meningkatkan performance/kinerja website, baik dari sisi kecepatan, kemudahan mengakses dan kelengkapan informasi dalam website tersebut, sehingga website akan sangat membantu pengguna dalam mencari informasi yang dibutuhkan [6]. Sehingga bisa diketahui aspek-aspek apa saja yang perlu diperbaiki dan dipertahankan terhadap layanan website Perguruan Tinggi Negeri di Bandar Lampung. 


\section{METODOLOGI}

Diagram alir dari penelitian yang dilakukan ditunjukkan pada Gambar 1.

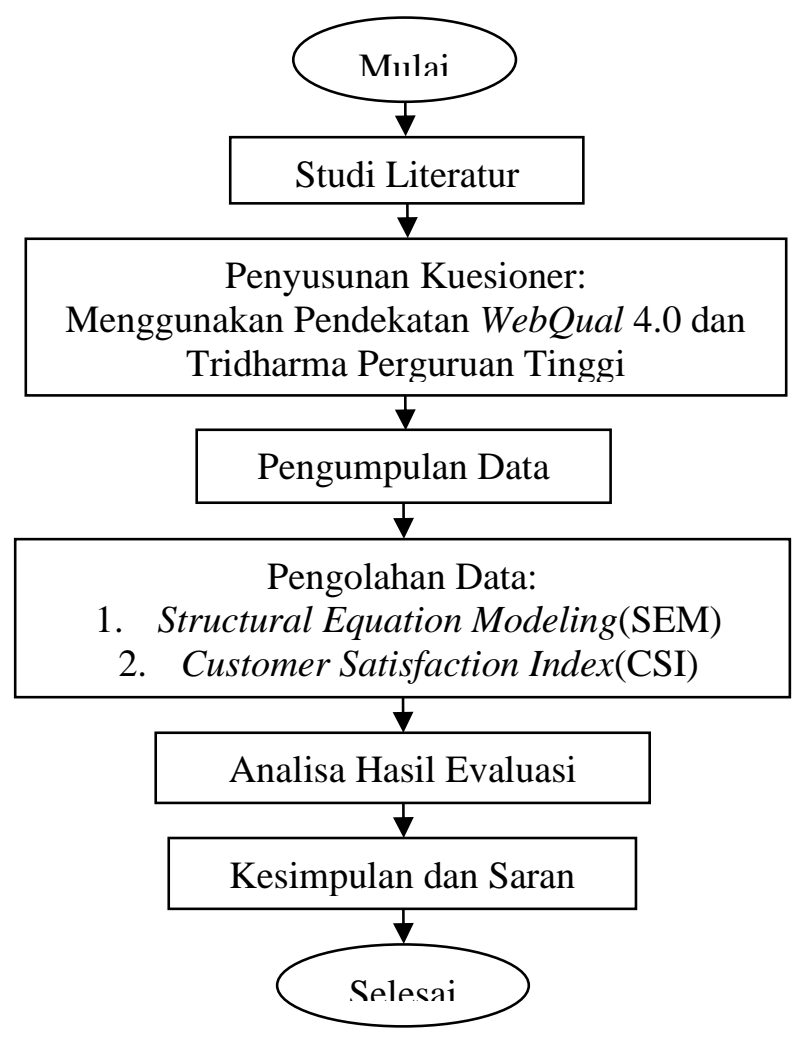

Gambar 1 Tahapan Penelitian

Metode pengumpulan data dilakukan dengan menggunakan kuesioner yaitu suatu metode pengumpulan data dengan cara menyebarkan daftar pertanyaanpertanyaan kepada para responden [4]. Populasi yang ditetapkan untuk penelitian ini adalah mahasiswa Perguruan Tinggi Negeri Bandar Lampung. Pada survei yang telah dilakukan diperoleh sebesar 77 responden untuk Universitas Lampung, 67 responden UIN Raden Intan, 47 responden Poltekkes Tanjung Karang, 52 responden Polinela, 51 responden Itera, dan 47 responden Universitas Terbuka. Skala pengukuran terbagi dalam beberapa skala yang masing-masing skala mempunyai skor penilaian 1-4 dimana skor 1 untuk jawaban terendah sampai dengan skor 4 untuk jawaban tertinggi.

Pertanyaan kuesioner dirumuskan sesuai dengan dimensi yang ada pada Metode WebQual 4.0 dan aspek-aspek yang ada pada Tridharma Perguruan Tinggi. Daftar pertanyaan berjumlah 25 pertanyaan dari dimensi webqual 4.0 dan 9 pertanyaan dari Tridharma Perguruan Tinggi. Pertanyaan dibagi ke dalam dua bagian yang merupakan pertanyaan tingkat harapan dan tingkat persepsi terhadap kualitas website. Pada tahap pengumpulan data, peneliti mengumpulkan data dengan menyebar kuesioner ditiap Perguruan Tinggi Negeri untuk mendapatkan nilai yang kongkret berdasarkan kepuasan pengguna. 
Pengolahan data pada penelitian ini menggunakan Structural Equation Model (SEM) dan Customer Satisfaction Index (CSI). SEM adalah suatu teknik statistik yang mampu menganalisis pola hubungan antara konstrak laten dan indikatornya, konstrak laten yang satu dengan lainnya, serta kesalahan pengukuran secara langsung [7]. Analisis ini digunakan untuk menguji hipotesis penelitian yang telah ditetapkan dengan menggunakan data sampel yang diperoleh. Data yang diperoleh dan responden yang dijadikan sebagai sampel penelitian melalui kuesioner yang disebarkan, akan dianalisis dengan menggunakan SEM berdasarkan program Partial Least Square (PLS). PLS digunakan untuk mengukur hubungan setiap indikator dengan konstruknya. Selain itu, dalam PLS dapat dilakukan uji bootstrapping terhadap struktural model yang bersifat outer model dan inner model [8].

\section{HASIL DAN PEMBAHASAN}

\subsection{Hipotesis Penelitian}

Dalam penelitian ini terdapat beberapa bentuk hubungan/persamaan (hipotesis) yang akan diuji, yaitu sebagai berikut.

a. Kualitas Layanan Website berpengaruh terhadap kepuasan pengguna website.

$\mathrm{H}_{0}=$ Terdapat hubungan yang tidak signifikan antara Kualitas Layanan Website terhadap kepuasan pengguna website.

$\mathrm{H}_{1}=$ Terdapat hubungan yang signifikan antara Kualitas Layanan Website terhadap kepuasan pengguna website.

b. Konten berpengaruh terhadap kepuasan pengguna website.

$\mathrm{H}_{0}=$ Terdapat hubungan yang tidak signifikan antara konten terhadap kepuasan pengguna website.

$\mathrm{H}_{1}=$ Terdapat hubungan yang signifikan antara konten terhadap kepuasan pengguna website.

c. Konten berpengaruh terhadap Kualitas Layanan Website.

$\mathrm{H}_{0}=$ Terdapat hubungan yang tidak signifikan antara konten terhadap kualitas layanan website.

$\mathrm{H}_{1}=$ Terdapat hubungan yang signifikan antara Konten terhadap kualitas layanan website.

\subsection{Evaluasi Structural Equation Modeling (SEM)}

Evaluasi pada SEM menggunakan dimensi Webqual 4.0 dan aspek-aspek yang ada pada Tridharma Perguruan Tinggi. Dimensi kualitas website yang digunakan pada penelitian ini terdiri atas tujuh kategori yaitu usability, kualitas informasi, interaksi pelayanan, kepuasan pegguna, aspek pendidikan, aspek penelitian, dan aspek pengabdian. Variabel berjumlah 25 yang merupakan dimensi webqual 4.0 dan 9 yang merupakan Tridharma Perguruan Tinggi. Sehingga berdasarkan dengan metode webqual dan aspek perguruan tinggi, didapat dimensi dan indikator kualitas layanan website sebagai berikut: 
Table 1 Dimensi dan variabel WebQual (Website Quality)

\begin{tabular}{cll}
\hline Dimensi & \multicolumn{1}{c}{ Variabel WebQual 4.0 } & Kode \\
\hline & Kemudahan untuk dioperasikan & USA1 \\
& Interaksi dengan website jelas dan dapat dimengerti & USA2 \\
& Kemudahan untuk navigasi & USA3 \\
& website mudah untuk digunakan & USA4 \\
& Website memiliki tampilan yang menarik & USA5 \\
& Desain sesuai dengan jenis website & USA6 \\
& Website mengandung kompetensi (petunjuk atau referensi yang & USA7 \\
& jelas) & USA8 \\
& Website menciptakan pengalaman positif bagi pengguna & IQ1 \\
& Menyajikan informasi yang akurat & IQ2 \\
& Menyajikan informasi yang dapat dipercaya & IQ3 \\
Information & Menyajikan informasi secara tepat waktu & IQ4 \\
Quality & Menyajikan informasi yang relevan & IQ5 \\
& Menyajikan informasi yang mudah dimengerti & IQ6 \\
& Menyajikan informasi dengan tingkat yang tepat & IQ7 \\
& Menyajikan informasi dengan format yang sesuai & SIQ1 \\
& memiliki reputasi yang baik & SIQ2 \\
& Pengguna merasa aman untuk melakukan akses pada website & SIQ3 \\
Service & Pengguna merasa aman terhadap informasi pribadinya & SIQ4 \\
Interaction & Website memberi ruang untuk personalisasi & SIQ5 \\
Quality & Memberikan ruang untuk komunitas (dosen / mahasiswa) & SIQ6 \\
& Memberikan kemudahan untuk berkomunikasi dengan organisasi & SIQ7 \\
& Menjamin tingkat kepercayaan yang tinggi atas informasi yang & \\
& disajikan & SAT1 \\
& Kinerja Website Perguruan Tinggi secara keseluruhan & SAT2 \\
Satisfaction & Layanan Website Perguruan Tinggi secara keseluruhan & SAT3 \\
\hline & Interaksi pengguna dengan Website Perguruan Tinggi & \\
\hline
\end{tabular}

Sumber: Dimensi dan Variabel Instrumen Webqual [1].

Tabel 1 Aspek Tridharma Perguruan Tinggi

\begin{tabular}{clc}
\hline \multicolumn{1}{c}{ Aspek } & \multicolumn{1}{c}{ Variabel Tridharma Perguruan Tinggi } & Kode \\
\hline & Informasi pendaftaran sebagai mahasiswa baru pada website Perguruan & PND1 \\
& Tinggi & \\
& Kegiatan akademik e-learning pada mahasiswa melalui website Perguruan & PND2 \\
Aspek Pendidikan & Tinggi & \\
& Kegiatan akademik KRS online pada mahasiswa melalui website Perguruan & PND3 \\
& Tinggi & PND4 \\
& Tersedianya lapangan pekerjaan dan jaringan sosial pada website bagi & \\
& alumni Perguruan Tinggi & PNL1 \\
Aspek Penelitian & Tersedianya link dalam website Perguruan Tinggi untuk Penelitian & PNL2 \\
& Informasi hasil penelitian pada Perguruan Tinggi & PNL3 \\
& Kerjasama untuk penelitian pada Perguruan Tinggi & PNG1 \\
Aspek Pengabdian & Hasil pengabdian pada Perguruan Tinggi & PNG2
\end{tabular}


Penyusunan path analisis pada penelitian ini tertera pada gambar 2 .

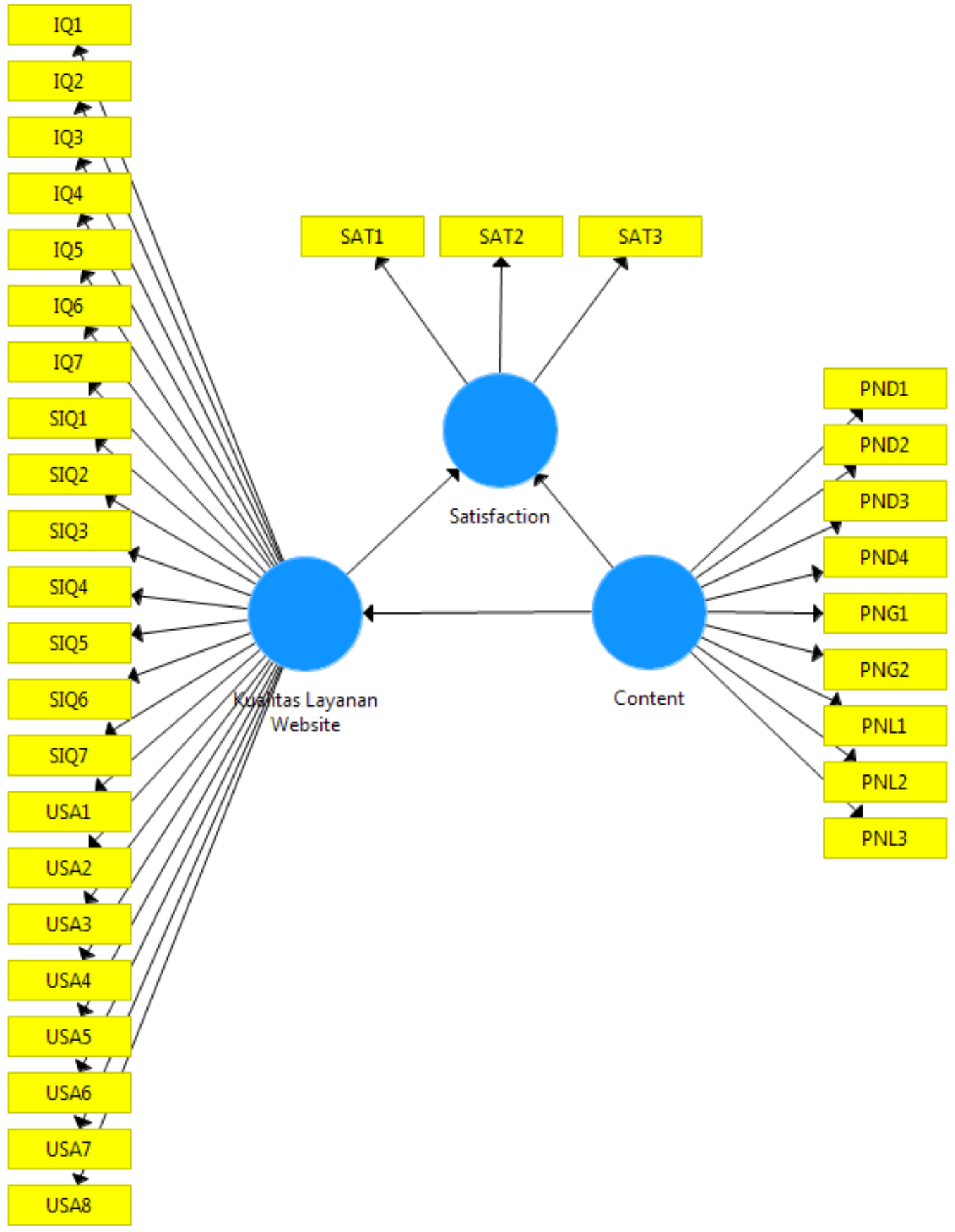

Gambar 2 Penyusunan Path Analisis

\subsection{Convergent Validity}

Pengujian validitas tahap pertama digunakan untuk mengidentifikasi bahwa unobserved variable dapat diukur dengan menggunakan masing-masing konstruk observed variable melalui Confirmatory Factor Analysis (CFA) atau biasa disebut dengan analisis faktor. Suatu indikator dianggap memiliki tingkat validitas yang tinggi apabila memiliki nilai faktor loading yang lebih besar dari 0,70. Namun indikator yang memiliki loading factor 0,50 sampai 0,60 masih dapat diterima. 
Dengan melihat nilai loading factor, indikator dengan nilai dibawah 0.5 akan direspesifikasi kembali [9].

Tabel 2 Nilai outer model pada website

Perguruan Tinggi Negeri Bandar Lampung

\begin{tabular}{|c|c|c|c|c|c|c|c|}
\hline \multirow{2}{*}{ Variabel } & \multirow{2}{*}{$\begin{array}{c}\text { Kode } \\
\text { Indikator }\end{array}$} & \multicolumn{6}{|c|}{ Outer Loading Value } \\
\hline & & Unila & UIN & Poltekkes & Polinela & Itera & UT \\
\hline \multirow{9}{*}{ Usability } & USA1 & & 0.808 & 0.667 & 0.697 & 0.693 & - \\
\hline & USA2 & 0.685 & 0.652 & 0.689 & 0.779 & 0.762 & 0.565 \\
\hline & USA3 & 0.628 & 0.693 & 0.771 & 0.628 & 0.546 & - \\
\hline & USA4 & 0.508 & 0.625 & 0.595 & 0.612 & 0.574 & 0.577 \\
\hline & USA5 & 0.696 & 0.676 & 0.822 & - & 0.626 & 0.603 \\
\hline & USA6 & 0.530 & - & 0.677 & 0.616 & 0.672 & 0.632 \\
\hline & USA7 & 0.685 & 0.748 & 0.657 & 0.740 & 0.607 & 0.763 \\
\hline & USA8 & 0.599 & 0.831 & 0.710 & 0.739 & - & 0.751 \\
\hline & IQ1 & 0.722 & 0.736 & 0.565 & 0.672 & 0.651 & 0.663 \\
\hline \multirow{6}{*}{$\begin{array}{c}\text { Information } \\
\text { Quality }\end{array}$} & IQ2 & 0.689 & 0.655 & 0.544 & 0.670 & 0.658 & 0.753 \\
\hline & IQ3 & 0.725 & 0.673 & - & 0.657 & 0.614 & 0.649 \\
\hline & IQ4 & 0.683 & 0.775 & 0.656 & 0.731 & 0.797 & 0.717 \\
\hline & IQ5 & 0.749 & 0.773 & 0.730 & 0.859 & 0.650 & 0.796 \\
\hline & IQ6 & 0.754 & 0.760 & 0.763 & 0.784 & 0.588 & 0.816 \\
\hline & IQ7 & 0.724 & 0.766 & 0.757 & 0.781 & 0.539 & 0.830 \\
\hline \multirow{7}{*}{$\begin{array}{c}\text { Service } \\
\text { Interaction } \\
\text { Quality }\end{array}$} & SIQ1 & 0.697 & 0.798 & 0.738 & 0.732 & 0.712 & 0.563 \\
\hline & SIQ2 & 0.570 & 0.722 & 0.541 & 0.672 & 0.668 & - \\
\hline & SIQ3 & 0.632 & 0.763 & - & - & 0.723 & - \\
\hline & SIQ4 & 0.630 & 0.661 & 0.545 & - & - & - \\
\hline & SIQ5 & 0.540 & - & 0.617 & - & - & - \\
\hline & SIQ6 & 0.621 & - & 0.765 & - & - & - \\
\hline & SIQ7 & 0.725 & 0.816 & 0.579 & 0.735 & 0.594 & 0.540 \\
\hline \multirow{3}{*}{$\begin{array}{c}\text { User } \\
\text { Satisfaction }\end{array}$} & SAT1 & 0.843 & 0.885 & 0.913 & 0.883 & 0.798 & 0.865 \\
\hline & SAT2 & 0.895 & 0.926 & 0.900 & 0.876 & 0.881 & 0.914 \\
\hline & SAT3 & 0.869 & 0.866 & 0.808 & 0.853 & 0.888 & 0.782 \\
\hline \multirow{4}{*}{$\begin{array}{c}\text { Aspek } \\
\text { Pendidikan }\end{array}$} & PND1 & 0.720 & 0.697 & 0.622 & 0.677 & 0.621 & 0.626 \\
\hline & PND2 & 0.808 & 0.795 & 0.756 & 0.812 & 0.723 & 0.851 \\
\hline & PND3 & 0.732 & 0.651 & 0.652 & 0.702 & 0.648 & 0.778 \\
\hline & PND4 & 0.800 & 0.804 & 0.792 & 0.762 & 0.558 & 0.670 \\
\hline \multirow{3}{*}{$\begin{array}{c}\text { Aspek } \\
\text { Penelitian }\end{array}$} & PNL1 & 0.833 & 0.792 & 0.843 & 0.691 & 0.761 & 0.723 \\
\hline & PNL2 & 0.863 & 0.772 & 0.817 & 0.723 & 0.739 & 0.666 \\
\hline & PNL3 & 0.873 & 0.843 & 0.784 & 0.836 & 0.738 & 0.724 \\
\hline Aspek & PNG1 & 0.859 & 0.825 & 0.789 & 0.755 & - & 0.760 \\
\hline Pengabian & PNG2 & 0.855 & 0.849 & 0.739 & 0.750 & - & 0.797 \\
\hline
\end{tabular}

(Sumber: data primer diolah, 2019)

Pengujian validitas tahap kedua yaitu pengujian discriminant validity. Pengujian ini didasarkan dari nilai cross loading pengukuran dengan konstruk dan nilai Average Variance Extracted (AVE). AVE yang baik, memiliki nilai lebih besar dari 0,50. 
Tabel 3 AVE Value pada website Perguruan Tinggi Negeri Bandar Lampung

\begin{tabular}{ccccccc}
\hline & \multicolumn{7}{c}{ AVE Value } \\
& Unila & UIN & Poltekkes & Polinela & Itera & UT \\
\hline $\begin{array}{c}\text { Kualitas Layanan } \\
\text { Website }\end{array}$ & 0.485 & 0.551 & 0.455 & 0.475 & 0.425 & 0.473 \\
$\quad$ & & & & & & \\
Satisfaction & 0.756 & 0.797 & 0.766 & 0.758 & 0.734 & 0.732 \\
$\quad$ Content & 0.669 & 0.609 & 0.575 & 0.558 & 0.428 & 0.542 \\
\hline
\end{tabular}

Tabel 4 menunjukkan nilai AVE dari model penelitian. Dapat dilihat dari tabel tersebut bahwa AVE Value untuk semua variabel penelitian telah bernilai di atas 0.5 , sehingga nilai AVE untuk pengujian discriminant validity sudah memenuhi untuk pengujian selanjutnya.

\subsection{Pengujian Realibilitas}

Berdasarkan metode PLS, reliabilitas indikator refleksif pada penelitian ini ditentukan dari nilai cronbach's alpha. Rule of thumb nilai alpha harus lebih besar dari 0,7 meskipun nilai 0,6 masih dapat diterima.

Tabel 4 Hasil output dari outer model dari croanbach's alpha

\begin{tabular}{ccccccc}
\hline & & \multicolumn{5}{c}{ Croanbach's Alpha (CA) } \\
& Unila & UIN & Poltekkes & Polinela & Itera & UT \\
\hline $\begin{array}{c}\text { Kualitas Layanan } \\
\text { Website }\end{array}$ & 0.937 & 0.954 & 0.936 & 0.940 & 0.893 & 0.917 \\
$\begin{array}{c}\text { Satisfaction } \\
\text { Content }\end{array}$ & 0.840 & 0.873 & 0.846 & 0.842 & 0.818 & 0.815 \\
& 0.938 & 0.920 & 0.906 & 0.900 & 0.676 & 0.894 \\
\hline
\end{tabular}

Tabel 5 merupakan tabel nilai croanbach's alpha dari model penelitian. Tabel tersebut menunjukkan bahwa setiap variabel telah memiliki nilai croanbach's alpha di atas 0.6 sehingga model penelitian tersebut telah memenuhi kriteria Reliabilitas.

\subsection{Uji Koefisien Determinasi / R Square $\left(\mathrm{R}^{2}\right)$}

Model struktural pada PLS dievaluasi dengan menggunakan $\mathrm{R}^{2}$ untuk konstruk dependen dan t-values untuk uji signifikan antarkonstruk pada model struktural [10]. Nilai $R$-square dari variabel dependen yang digunakan didalam model dapat dilihat pada Tabel 6.

Tabel 5 Nilai R-square pada konstruk berdasarkan output dari smartPLS 4.0.

\begin{tabular}{ccccccc}
\hline & & \multicolumn{5}{c}{$R$-Square $\left(\mathrm{R}^{2}\right)$} \\
& Unila & UIN & Poltekkes & Polinela & Itera & UT \\
\hline $\begin{array}{c}\text { Satisfaction } \\
\text { Kualitas Layanan } \\
\text { Website }\end{array}$ & 0.535 & 0.589 & 0.691 & 0.519 & 0.498 & 0.294 \\
& 0.517 & 0.597 & 0.501 & 0.631 & 0.261 & 0.519
\end{tabular}




\subsection{Uji Hipotesis}

Uji ini dapat dilakukan dengan membandingkan T-Statistic smartPLS dengan t-tabel. Pada penelitian ini, peneliti mengambil tingkat signifikansi sebesar 0.05 atau $5 \%$. Besarnya koefisien keyakinan yang digunakan adalah $95 \%$ dengan nilai $\alpha$ (alpha) sebesar 5\% sehingga nilai t values $>1,96$. Setelah uji hipotesis dilakukan, diperoleh hasil seperti Tabel 7.

Tabel 6 Hasil uji hipotesis

\begin{tabular}{|c|c|c|c|c|c|c|c|}
\hline \multirow[b]{2}{*}{ No } & \multirow[b]{2}{*}{ Hipotesis } & \multicolumn{6}{|c|}{ T value website Perguruan Tinggi Negeri } \\
\hline & & Unila & UIN & $\begin{array}{c}\text { Poltek } \\
\text { kes }\end{array}$ & $\begin{array}{c}\text { Polinel } \\
\mathrm{a}\end{array}$ & Itera & UT \\
\hline & Kualitas Layanan & 3.451 & 3.073 & 8.623 & 1.518 & 7.028 & 1.197 \\
\hline 1 & $\begin{array}{l}\text { Website } \rightarrow \\
\text { Kepuasan }\end{array}$ & $\checkmark$ & $\checkmark$ & $\sqrt{ }$ & $x$ & $\checkmark$ & $x$ \\
\hline 7 & Konten $\rightarrow$ & 1.010 & 1.674 & 0.337 & 2.220 & 0.163 & 0.871 \\
\hline 2 & Kepuasan & $x$ & $x$ & $x$ & $\checkmark$ & $x$ & $x$ \\
\hline & Konten $\rightarrow$ & 10.807 & 23.917 & 10.308 & 17.346 & 3.898 & 15.64 \\
\hline 3 & $\begin{array}{c}\text { Kualitas Layanan } \\
\text { Website }\end{array}$ & $\checkmark$ & $\checkmark$ & $\checkmark$ & $\checkmark$ & $\checkmark$ & $\checkmark$ \\
\hline
\end{tabular}

Berdasarkan hasil nilai T-Statistics SmartPLS pada tabel 7 bahwa Konten mempunyai pengaruh signifikan terhadap kualitas layanan website Perguruan Tinggi Negeri di Bandar Lampung. Pada hasil uji hipotesis antara kualitas layanan website terhadap kepuasan, kualitas layanan website mempunyai pengaruh signifikan terhadap kepuasan pengguna website, kecuali pada website Polinela dan UT. Pada hasil uji hipotesis antara konten dengan kepuasan, konten mempunyai pengaruh tidak signifikan terhadap kepuasan pengguna website, kecuali pada websitePolinela.

\subsection{Pengolahan Data Menggunakan Customer Satisfaction Index (CSI)}

Perhitungan customer satisfaction index menggunakan nilai skor rata-rata tingkat kepentingan dan tingkat kinerja dari masing masing atribut [11]. Cara menghitung indeks kepuasan pelanggan adalah:

a. Menghitung Weighting Factors (WF). Yaitu fungsi dari tingkat kepentingan masing-masing atribut dalam bentuk persentase (\%) dari total skor median tingkat kepentingan untuk seluruh atribut yang diuji.

b. Menghitung Weighted Score (WS). Yaitu fungsi dari skor median tingkat kepuasan masing-masing atribut dikalikan dengan Weighting Factors (WF) masing-masing atribut.

c. Menghitung Weighted Median Total (WMT). Yaitu total dari nilai Weighted Score (WS) secara keseluruhan.

d. Menghitung Customer Satisfaction Index.(CSI). Yaitu perhitungan dari Weighted Median Total (WMT) dibagi skala maksimum, kemudian dikali 100\% [12]. 
Nilai CSI dalam penelitian ini dibagi dalam lima kriteria dari tidak puas sampai dengan sangat puas seperti yang terdapat pada tabel 8 .

Tabel 7 Kriteria Nilai Customer Satisfaction Indeks (CSI) [12]

\begin{tabular}{ccl}
\hline No & Nilai Index & Keterangan \\
\hline 1 & $81 \%-100 \%$ & Sangat Puas \\
2 & $66 \%-80 \%$ & Puas \\
3 & $51 \%-65 \%$ & Cukup Puas \\
4 & $35 \%-50 \%$ & Kurang Puas \\
5 & $0 \%-34 \%$ & Tidak Puas \\
\hline
\end{tabular}

Tabel 8 Nilai Customer Satisfaction Index (CSI)

\begin{tabular}{cccc}
\hline No. & Perguruan Tinggi & $\begin{array}{c}\text { Nilai Customer Satisfaction Index } \\
\text { (CSI) }\end{array}$ & Keterangan \\
\hline 1 & Unila & $71,72 \%$ & Puas \\
2 & UIN & $78,09 \%$ & Puas \\
3 & Poltekkes & $80,44 \%$ & Puas \\
4 & Polinela & $75,77 \%$ & Puas \\
5 & Itera & $78,49 \%$ & Puas \\
6 & UT & $79,97 \%$ & Puas \\
7 & Perguruan Tinggi & $76,92 \%$ & Puas \\
\hline
\end{tabular}

Berdasarkan nilai Customer Satisfaction Index (CSI) pada tabel 9 diperoleh tingkat kepuasan customer paling rendah sebesar $71,72 \%$ yaitu pada website Unila dan paling tinggi sebesar $80,44 \%$ yaitu pada website Poltekkes. Nilai CSI ini diperoleh dari pembagian antara total nilai Weight Score (WS) dengan skala maksimum yang digunakan dalam penelitian ini yaitu 4 dan mengalikan dengan $100 \%$. Hasil penelitian pada tiap website perguruan tinggi, diperoleh nilai indeks kepuasan berada pada rentang $66 \%$ - $80 \%$ yang berarti secara keseluruhan pengguna website merasa puas terhadap kualitas kinerja website di tiap perguruan tinggi. Hal ini menunjukkan bahwa secara umum pengguna website puas terhadap atribut-atribut pada website di tiap perguruan tinggi.

\subsection{Evaluasi Website Menggunakan Tools}

Untuk meningkatkan usability suatu website dapat dilakukan pengujian website performance dengan menggunakan Automatic Tools [6]. Dalam penelitian ini, digunakan 6 tools pengukuran kegunaan website. Evaluasi pengujian website performance dilakukan pada hari Senin, 21 Mei 2018. Rekapitulasi nilai evaluasi website menggunakan tools pada website Perguruan Tinggi Negeri di Bandar Lampung dapat dilihat pada Tabel 10. 
Tabel 9 Nilai evaluasi website menggunakan tools

\begin{tabular}{cccccccc}
\hline No & $\begin{array}{c}\text { Perguruan } \\
\text { Tinggi }\end{array}$ & $\begin{array}{c}\text { Error } \\
\text { HTML }\end{array}$ & $\begin{array}{c}\text { Traffic } \\
\text { Visitor }\end{array}$ & $\begin{array}{c}\text { Page } \\
\text { Load } \\
\text { Time }\end{array}$ & $\begin{array}{c}\text { Page } \\
\text { Size }\end{array}$ & $\begin{array}{c}\text { Link } \\
\text { Rusak }\end{array}$ & $\begin{array}{c}\text { File } \\
\text { Terindeks }\end{array}$ \\
\hline 1 & Unila & 35 & 5.258 & 1.98 & $2.98 \mathrm{MB}$ & 12 & 222000 \\
2 & UIN & 25 & 659 & 2.71 & $3.20 \mathrm{MB}$ & 14 & 8020 \\
3 & Poltekkes & 153 & 987 & 1.47 & $3.56 \mathrm{MB}$ & 3 & 567 \\
4 & Polinela & 61 & 206 & 1.28 & $1.58 \mathrm{MB}$ & 7 & 1300 \\
5 & Itera & 76 & 149 & 1.77 & $5.69 \mathrm{MB}$ & 12 & 400 \\
6 & UT & - & - & 2.43 & - & - & 20700 \\
\hline
\end{tabular}

Berdasarkan nilai evaluasi website menggunakan tools pada website Perguruan Tinggi Negeri di Bandar Lampung pada tabel 10 bahwa Usability pada website Perguruan Tinggi Negeri di Bandar Lampung sudah baik, terbukti dengan nilai page load time yang kurang dari 3 seconds dan jumlah broken link yang sedikit.

HTML error terbanyak adalah website Poltekkes, dan HTML error terdikit adalah website UIN. Artinya website Poltekkes Tanjung Karang memiliki kualitas yang buruk pada usability. Karena semakin banyak html error yang dimiliki oleh website, maka semakin buruk kualitas usability website tersebut. Jumlah pengunjung website terbanyak adalah Universitas Lampung yaitu 5.258 pengunjung per hari, dan jumlah pengunjung website paling sedikit adalah Institut Teknologi Sumatera (Itera) yaitu 149 pengunjung rata-rata perhari. Artinya website Itera memiliki kualitas konten yang sangat rendah dan juga memiliki SEO (Search Engine Optimization) yang kurang baik. Jumlah pengunjung atau jumlah halaman yang diakses pengunjung dapat mempengaruhi tingkat popularitas website. Untuk meningkatkan jumlah pengunjung pada website yaitu website harus memperbanyak konten atau memiliki konten yang berkualitas baik.

Nilai page size terkecil adalah website Polinela yaitu sebesar 1.58MB, dan nilai page size terbesar adalah website Itera yaitu sebesar 5,69MB. Terdapat website yang memiliki ukuran yang sangat besar, namun juga terdapat website yang memiliki ukuran sangat kecil. Besar-kecilnya pagesize tergantung komponen dalam website seperti: ukuran gambar, ukuran HTML file, ukuran CSS file, dan sebagainya. Pagesize yang semakin besar akan membutuhkan waktu semakin lama untuk mengunduh halaman website. Page size yang besar akan memperlambat page load time suatu website. Salah satu cara untuk mengurangi page size dengan melakukan efisiensi desain halaman website dengan meminimalisir jumlah subpage yang ada dalam website.

Jumlah file terindeks terbanyak adalah website Unila yaitu 222000, dan jumlah file terindeks yang paling sedikit adalah website Itera yaitu 400. File terindeks mengacu pada keakuratan informasi yang disediakan oleh suatu website yang dapat dideteksi oleh mesin pencari dan juga kualitas serta volume dari konten sebuah website tersebut [6]. 


\section{SIMPULAN DAN SARAN}

\subsection{Simpulan}

Simpulan dari hasil pengukuran kualitas layanan website Perguruan Tinggi Negeri di Bandar Lampung yaitu sebagai berikut.

a. Hasil uji hipotesis SmartPLS website Perguruan Tinggi Negeri di Bandar Lampung diketahui bahwa Konten mempunyai pengaruh signifikan terhadap kualitas layanan website, Kualitas layanan website mempunyai pengaruh signifikan terhadap kepuasan pengguna website, kecuali pada website Polinela dan UT, dan Konten tidak mempunyai pengaruh signifikan terhadap kepuasan pengguna website, kecuali pada website Polinela.

b. Hasil Customer Satisfaction Index (CSI) pada website Perguruan Tinggi Negeri di Bandar Lampung merasa puas atas pelayanan website pada masing-masing Perguruan Tinggi Negeri.

c. Usability pada website Perguruan Tinggi Negeri di Bandar Lampung sudah baik, terbukti dengan nilai page load time yang kurang dari 3 detik.

\subsection{Saran}

Saran yang dihasilkan pada penelitian pengukuran kualitas layanan website Perguruan Tinggi Negeri di Bandar Lampung yaitu sebagai berikut.

a. Hasil dari pengukuran kualitas layanan website dapat dijadikan rekomendasi bagi pengembang website Perguruan Tinggi.

b. Dalam penelitian selanjutnya dapat menggunakan metode lain untuk mendapatkan perbandingan hasilnya.

c. Menerapkan SEO untuk meningkatkan usability dari suatu website.

\section{REFERENSI}

[1] Napitupulu, D. B., "Evaluasi Kualitas Website Universitas XYZ Dengan Pendekata Webqual (Evaluation of XYZ University Website Quality Based on Webqual Approach)", Buletin Pos Dan Telekomunikasi, 14(1), 51, 2016.

[2] Budi, R. F., "Pengaruh Kualitas Web Terhadap Tingkat Kepuasan Penggunaan Google Scholar (Studi Pada Mahasiswa Unair Sebagai Penunjang Kegiatan Akademis)", Libri-Net, 2(1), 1-20, 2013.

[3] Imam, A., "Rancang Bangun Penilaian Kualitas Website Untuk Mengukur GAP Kualitas Antara Harapan Dan Persepsi Pengguna (Studi Kasus Analisa GAP Kualitas di Website www.polinela.ac.id)", Masters Thesis, Universitas Diponegoro, 2012.

[4] Sibyan, H., Soedijono, B. W. A., \& Sofyan, A. F., "Pengukuran Kualitas Layanan Website Fakultas Teknik dan Ilmu Komputer UNSIQ Wonosobo”, PPKM III, 174-184, 2016.

[5] Maiyanti, S. I., "Aplied Customer Satisfaction Index (CSI) and ImportancePerformance Analysis (IPA) to know Student Satisfaction Level of Sriwijaya University Library Services", Seminar Nasional Matematika dan Pendidikan Matematika, Universitas Muhammadiyah Malang, 7-18, 2010. 
[6] Hanifah, R., "Perangkingan Usability Website menggunakan Metode Multiple Criteria Decision Analisys", TICOM, 5(1), 7-15, 2016.

[7] Rahmadaniaty, N., Masniari, R., \& Arnita, "Penerapan metode SEM dalam menentukan pengaruh kepuasan, kepercayaan dan mutu terhadap kesetiaan pasien rawat jalan dalam memanfaatkan pelayanan rumah sakit di RSUD Dr. Pirngadi Medan", Jurnal Kebijakan, Promosi Kesehatan, Dan Biostatistik, 2(1), 1-10, 2013.

[8] Hussein, A. S., "Penelitian Bisnis dan Manajemen Menggunakan Partial Least Squares (PLS) dengan SmartPLS 3.0.", Modul Ajar, 1-29, 2015.

[9] Alfidella, S., Kusumo, D. S., \& Suwawi, D. D. J., "Pengukuran Usability I-Caring Berbasis ISO 9241-11 Dengan Menggunakan Partial Least Square (PLS)" eProceedings of Engineering, 2(1), 1747-1735, 2015.

[10] Haryani, P., "Evaluasi Kualitas Layanan E-Government Pemerintah Kota Yogyakarta Dengan Metode E-Govqual Modifikasi”, Simposium Nasional RAPI XV, 379-386, 2016.

[11] Mahardika, S. A. T., Santoso, I., \& Silalahi, R. L. R., "Penilaian Kepuasan Konsumen Terhadap Kualitas Susu Pasteurisasi Kop Sae Pujon (Studi Kasus Pada Koperasi Susu Sae Pujon)”, Industria, 4(1), 10-20, 2015.

[12] Hekhmatyar, O. G., \& Supriyadi, D., "Measurement Satisfaction Information System Quality Service On BSI Using Webqual And CSI", Indonesian Jurnal on Computer and Information Technology, 2(2), 1-6, 2017. 